\title{
The implementation of a century foreign experience of affordable housing in construction management - a new format of economy in Russia
}

\author{
Leyla Leonova*, Anatoly Fedorov, and Tomash Czerny \\ Ural Federal University named after the first President of Russia B.N. Yeltsin, 620002, Mira Str., 19, \\ Ekaterinburg, Russia (Czech Republic)
}

\begin{abstract}
The article is devoted to the formation and history of the creation of a unique organizational model for managing the construction of affordable (social) housing on the example of the capital of Austria. The relevance of the functioning of such a model is indisputable, since at present, multiscale migration processes are taking place in large cities not only in the EU countries, but also in Russia. Moreover, migration takes place mainly from third world countries. In such conditions, there is an acute issue of providing the population with affordable, comfortable housing, without disturbing historical and architectural monuments. This model was formed and has been successfully operating in Vienna for over 100 years. Its uniqueness lies in the fact that the main role in it is played by the municipal authorities. Exactly they create social programs in the field of housing construction and funding them. At the same time, the rental housing market is becoming more comfortable and of high quality. The principles of social justice in the housing market for socially disadvantaged groups of the population are observed.

This model of the functioning and formation of the affordable housing market in Vienna, according to the authors of the article, personifies the formation and functioning of the socio-economic cluster in the housing and communal sector. Of course, such a positive experience of providing the country's citizens with affordable and comfortable apartments is possible and necessary to apply in Russia.
\end{abstract}

\section{Introduction}

Currently, a significant growth of cities is not only in Russia, but also in the European countries. The urbanization process is inevitable. It occurs not so much due to the growth of the indigenous population, but mainly due to migration from rural areas, as well as migration from third world countries. This is undoubtedly the reason for the lack of affordable housing for the growing population of large cities. Each city resolves this issue in its own way. According to the authors of the article, it is interesting to consider, and perhaps transform the experience of the European capital, Vienna, into other cities and especially in Russia. 
The modern model of housing policy has existed here for over 100 years

$[1,2]$. Over a century of history in Vienna, a unique model of housing policy has been formed, but it is completely different from other European cities. In most cities in EU countries, municipalities have given housing market to private ownership. While in Vienna the housing market management is completely carried out under the control of the city authorities, which almost control housing prices, making it affordable for the majority of the city's population $[1,2]$.

In the capital of Austria, as in other cities in Europe, there is a rapid increase in the city's population, especially due to migrants. And this motivates the city authorities to make a great effort to provide the city's population not only with affordable but also comfortable housing [2].

The basic principles of the development of the affordable housing market, including social housing in Austria are the following:

1. Leading role of non-profit developers,

2. Direct subsidies for housing construction from the state,

3. Control by the municipality over the rent for housing,

4. Control over the cost of rent in newly built houses.

These principles are relevant to this day, while the market and market relations are increasingly beginning to prevail $[1,2]$.

An important feature of Vienna is the fact that this city has been always imperial, had a rich history (the first mention dates back to 881), a magnificent historical heritage and unique architecture. Today the population of the city is over than 1.8 million people (2019).

The Vienna authorities have good achievements in housing policy today:

1. There are preserved monuments of architecture,

2. Well-developed legislation in the field of urban construction,

3. Close relationships and connections with citizens, taking into account their interests [3].

Vienna has become a role model and best practice for the EU countries today, especially after the economic crisis in 2008. Specialists in the field of housing policy of this city always take part in international conferences on housing policy in the field of construction of affordable housing everywhere [4].

\section{Research methods}

The work used general scientific methods of dialectics, analysis, synthesis, analogy. The methodological basis was the elements of the theory of comparative analysis. A tabular method was used for the purpose of visual interpretation of theoretical information.

\section{Results and discussion}

The history of the development of the social housing system in Vienna dates back to the early 20 th century.

It should be noted that at the beginning of the twentieth century, ownership of residential real estate in the city was private. From 1918 to the present time, the ownership of residential real estate is considered municipal, and residential premises are rented mainly for rent. But in 2006, residential real estate in the city became partly municipal, partly private.

A historical overview of the development of the affordable housing system is given in Table 1. 
Table 1. Stages of construction of affordable housing in Vienna according to [3-7]

\begin{tabular}{|c|c|c|}
\hline Period (years) & The essence of development & Results and achievements \\
\hline $\begin{array}{l}\text { The beginning } \\
\text { of } X X \text { century }\end{array}$ & $\begin{array}{l}2 \text { types of projects are being implemented: } \\
\text {-construction of small apartments with many } \\
\text { tenants and unsatisfactory sanitary conditions; } \\
\text { - construction of luxury apartments in new } \\
\text { apartment buildings }\end{array}$ & $\begin{array}{l}\text { Low comfort conditions, } \\
\text { crowded population. } \\
\begin{array}{l}\text { Differentiation and social } \\
\text { stratification of the city } \\
\text { population }\end{array}\end{array}$ \\
\hline $1918-1934$ & $\begin{array}{l}\text { Large residential areas were built on the outskirts. } \\
\text { Houses are multi-apartment buildings made of } \\
\text { concrete with a high degree of improvement } \\
\text { (water supply, sewerage, electricity). } \\
\text { The total area of most of the apartments was } 40 \\
\text { square meters, the smaller part was from } 49 \text { to } 57 \\
\text { square meters. }\end{array}$ & $\begin{array}{l}61,723 \text { apartments were } \\
\text { built, } 348 \text { residential blocks } \\
\text { appeared, which formed } 42 \\
\text { settlements, where a tenth } \\
\text { of the city's population } \\
\text { lived }\end{array}$ \\
\hline $\begin{array}{l}\text { The second } \\
\text { world war } \\
\text { and after till } \\
1947 \text { year }\end{array}$ & $\begin{array}{l}\text { A large number of houses were destroyed and } \\
\text { housing construction fell into disrepair. }\end{array}$ & - \\
\hline $1950-s$ & $\begin{array}{l}\text { Adoption of a new construction program. } \\
\text { involving the construction of highly comfortable } \\
\text { two-level apartments in low-rise buildings. All } \\
\text { new development areas were equipped with } \\
\text { infrastructural social facilities }- \text { schools, } \\
\text { kindergartens, healthcare, recreation, shops. } \\
\text { Further improvement of housing (appearance of } \\
\text { bathrooms, central heating and hot water supply) }\end{array}$ & $\begin{array}{l}\text { Creation of comfortable and } \\
\text { affordable living conditions } \\
\text { for the majority of the city's } \\
\text { population. Comprehensive } \\
\text { development of territories } \\
\text { through the implementation } \\
\text { of the construction of } \\
\text { infrastructure facilities }\end{array}$ \\
\hline $1951-1970$ & $\begin{array}{l}\text { There was a modernization of apartments, which } \\
\text { affected } 170,000 \text { apartments. It was during these } \\
\text { years that a system of subsidies for housing } \\
\text { construction was created, and most of the money } \\
\text { from the municipal budget was directed to the } \\
\text { renovation of old private rented buildings. }\end{array}$ & $\begin{array}{l}\text { Further improvement of } \\
\text { comfort for the majority of } \\
\text { the population. The } \\
\text { maximum allowable rental } \\
\text { rate of } 1 \text { shilling per a } \\
\text { square meter per month has } \\
\text { been reached. }\end{array}$ \\
\hline $\begin{array}{l}\text { From } 80-s . \text { of } \\
\text { XX century }\end{array}$ & $\begin{array}{l}\text { It became necessary to build an average of } 10,000 \\
\text { housing units per year due to high migration } \\
\text { activity. }\end{array}$ & $\begin{array}{l}\text { A sharp increase in housing } \\
\text { construction. }\end{array}$ \\
\hline $90-s$ & $\begin{array}{l}\text { Sharp growth in demand for housing due to high } \\
\text { migration activity from the countries of the } \\
\text { socialist camp }\end{array}$ & $\begin{array}{l}\text { An increase in the rate of } \\
\text { housing construction } \\
\text { doubled to } 10,000 \text { housing } \\
\text { units per a year }\end{array}$ \\
\hline $\begin{array}{l}\text { The beginning } \\
\text { of XXI century }\end{array}$ & $\begin{array}{l}\text { An increase in the density of the city, a change in } \\
\text { the structure of the population, an increase in the } \\
\text { proportion of one-person households The } \\
\text { emergence of new thematic projects such as } \\
\text { Bike-City }\end{array}$ & $\begin{array}{l}\text { Construction of modern } \\
\text { multicultural and energy- } \\
\text { efficient residential areas. }\end{array}$ \\
\hline $2010-2020$ & $\begin{array}{l}\text { Further development of the system for the } \\
\text { construction of affordable housing and the } \\
\text { allocation of state subsidies for } 50 \% \text { of } \\
\text { apartments under construction. }\end{array}$ & $\begin{array}{l}\text { Increase in the quality and } \\
\text { comfort of living in the city. }\end{array}$ \\
\hline
\end{tabular}

It should be mentioned that world-class architectural objects were built, typical of their time have been built even in conditions when the construction of apartments in Vienna was carried out mainly for the workers and socially unprotected segments of the population. Among them, are the following districts: Karl Marx Hof, The George-Washington-Hof, Großfeldsiedlung, Wohnpark Alt Erla Rabenhof, Sandleiten and others [6]. 
The last municipal housing estate for which the Vienna City Council acted as a building contractor, at Rößlergasse no.15, was completed in 2004. The entire city's subsidized housing program has been turned over to nonprofit housing associations and cooperatives also at the same time. Today, every fourth citizen of Vienna lives in one of the 1800 municipal housing estates in the city [2].

Legislation. It should be noted that the housing policy of the Vienna City authorities was accompanied by the adoption of relevant legislative acts.

Legislative acts, starting from 1922 and existing standards at the present time, we will enter in table 2.

Table 2. Legislation in Vienna on housing construction (compiled by the authors based on [2])

\begin{tabular}{|l|l|}
\hline Period & \multicolumn{1}{|c|}{ Title of the law } \\
\hline 1922 & $\begin{array}{l}\text { The law to protect the rights of tenants of apartments from excessive } \\
\text { rents and prohibiting the eviction of widows and war veterans. }\end{array}$ \\
\hline 1929 & First Building Act \\
\hline 1954 & Housing Support and Promotion Act \\
\hline 1968 & Private Housing Finance Act \\
\hline 1969 & Housing Renovation Act \\
\hline 1974 & Law on the renovation of transport and technical infrastructure \\
\hline 1981 & Housing Tenant Rights Act \\
\hline 1984 & Establishment Act of the Vienna City Renovation Fund \\
\hline 1995 & $\begin{array}{l}\text { Law on the competitive selection of designers and construction } \\
\text { contractors }\end{array}$ \\
\hline 1997 & $\begin{array}{l}\text { Creation of the Big Vienna agglomeration for the implementation of } \\
\text { housing construction }\end{array}$ \\
\hline 2000 & $\begin{array}{l}\text { Correction and updating of the entire regulatory framework in the field } \\
\text { of housing construction }\end{array}$ \\
\hline
\end{tabular}

Since 1995, competitions for designers and contractors have begun, for this, projects are evaluated not only from an architectural and quality point of view, but also from an economic and environmental point of view, social sustainability and significance are also assessed [2].

In 1997, the housing departments of the municipal districts were merged and a joint department was created within the "big" city of Vienna. In 2000, it became the independent city company Wiener Wohnen. In 2004, the implementation of municipal apartments was transferred from the knowledge of the city to charity construction companies. The municipal land is sold to a developer and support is provided in the amount of $1 / 3$ of the construction cost in the form of a long-term loan at a reduced rate. In recent years, Wiener Wohnen's operations departments have been centralized for greater efficiency, and direct services have been decentralized for better accessibility [6]. Now, according to the company's official website, Wiener Wohnen operates about 220,000 municipal housing units, 5,129 restaurants, and more than 47,000 garages and parking spaces [6].

However, after Austria's accession to the European Union, the Vienna City Council was no longer able to build apartments on the same scale alone and compete with private developers. Therefore, the municipality completed its own housing construction in 2003 [6]. Today, instead of building housing, the city has begun supporting private and cooperative housing projects in exchange for adhering to rules of social responsibility and cohesion. The developer can receive support in the amount of up to one third of the 
construction cost, but for this he must undertake to set only the specified maximum rent for an indefinite period, which can be increased only after agreement with the city administration [7].

The subsidized housing sector forms the backbone of the housing market in Vienna, which gives the municipal authorities a great influence on the formation and development of the city. This prevents speculation in the housing market, since aggressive real estate investment is not profitable given high saturation in a cheap subsidized market. The preferred form of ownership to this day is rent [8].

The state, represented by the city authorities, provides competition among developers who must build comfortable residential buildings that meet modern architectural and environmental requirements, while remaining accessible to all categories of the population. All this provides both good functionality and social support in all residential areas of the city [8].

Today more than half a million people live in 220,000 social homes thanks to the longterm policy. $80 \%$ of Vienna residents live in rented apartments and houses. At the same time, about $60 \%$ of Viennese rent housing with a "ceiling" of rent set by the municipal authorities. And only about 5\% - 7.4\% of rented apartments in Vienna are subject to competitive market laws and are not social [9].

Between 2008 and 2018, rents in the private sector increased by $42 \%$, and speculation on the land market in the city, which is experiencing a boom in the residential real estate market, makes it increasingly difficult and in the long term impossible to build affordable housing [9].

The residential real estate market is designed in such a way that apartments are available for the middle class, but not for the rich people. For example, a person who wants to live alone in a subsidized or city apartment must have a net income of no more than double the Austrian average. The distribution of apartments is determined by the waiting list, the duration and waiting time depend on the requirements of the candidate [10].

Tenants are also subject to mandatory conditions, such as:

1. reaching the age at 17 ,

2. citizenship of Austria or EU countries,

3. asylum or legal residence in Austria for two years,

4. regulated monthly income of 3000 euros,

5. legalized family relationships.

In addition, borrowers must meet at least one of the so-called additional conditions:

1. "overcrowding" or health-threatening existing apartment,

2. health status,

3. old age,

4. limited mobility, etc.

The person, who wants to enter the waiting list, submits an official application accompanied by the established documents. The waiting period currently ranges from one to two years. After finding a suitable apartment, the applicant is invited to visit it. If the applicant refuses the offered apartment, he is obliged to substantiate his decision, in case of two consecutive refusals he is excluded from the database for 3 years. Another option for obtaining an apartment is its direct transfer, in which the new tenant accepts the apartment directly from the current tenant, thus freeing the Wiener Wohnen administration. There is also the possibility of receiving regular direct Vienna housing benefits for low-income families. In this case, distribution is governed by the rule that the allowance must cover the cost of housing up to a level that does not exceed approximately 20-25 percent of household income [3].

The tenant's rights in Austria are protected by the state, and therefore, from the point of view of prestige, they have the same status, which is equated to the status of the owner - 
homeowner. The private landlord has the option to terminate the lease with a three month notice period, while the cooperative or municipality cannot terminate the lease if at least part of the lease is fulfilled [9].

Only Austrian citizens had access to municipal housing in some regions until 2006, however, with the formation of the EU, the rules changed. Citizenship is difficult to obtain and can only be obtained after 15 years of permanent residence in the country. Vienna, the region with the highest concentration of immigrants in Austria, has already opened up access to municipal housing for them. In addition, $1 / 3$ of the population are foreigners, so it was necessary to amend the housing legislation [11].

New municipal housing is populated mainly by young middle-class families. Young families tend to live in new houses, while older people and other categories of citizens can live in secondary housing. The municipal housing market in Vienna is polarized [4].

Let's compare the development of the housing system in Russia and Austria (see table $3)$.

Table 3. Comparison of the development of the affordable social housing market in Russia and Austria (compiled by the authors)

\begin{tabular}{|c|c|c|}
\hline Comparison criterion & Austria & Russia \\
\hline Legislative base & $\begin{array}{l}\text { Formed since the } 20 \mathrm{~s} \text { of the } 20 \text { th } \\
\text { century, with subsequent updating }\end{array}$ & $\begin{array}{l}\text { Completely changed after } 1990- \\
2000\end{array}$ \\
\hline $\begin{array}{l}\text { Period of development of the } \\
\text { housing construction system }\end{array}$ & $\begin{array}{l}\text { From the beginning of the } 20 \text { th } \\
\text { century }\end{array}$ & From the $50 \mathrm{~s}$ of the 20 th century \\
\hline $\begin{array}{l}\text { The share in the housing stock of } \\
\text { cities }\end{array}$ & $\begin{array}{l}\text { Rental housing - } 80 \% \text {, of which } \\
\text { most }(60 \%) \text { have a "ceiling rent" } \\
\text { set by the city authorities, owned } \\
\text { housing }-5-7 \%\end{array}$ & $\begin{array}{l}94 \% \text { of the housing market is } \\
\text { owned }\end{array}$ \\
\hline Development priorities & $\begin{array}{l}\text { Compliance with the principles of } \\
\text { social justice }\end{array}$ & Priority of market principles \\
\hline State regulation & $\begin{array}{l}\text { Municipalities regulate rental rates } \\
\text { and finance the construction of } \\
\text { affordable housing }\end{array}$ & $\begin{array}{l}\text { Complete dictate of the market, the } \\
\text { cost of } 1 \text { sq. } m \text {. depends on the } \\
\text { location of the object in relation to } \\
\text { the city center }\end{array}$ \\
\hline $\begin{array}{l}\text { Terms of obtaining social } \\
\text { housing }\end{array}$ & $1-2$ years & 10 or more years \\
\hline The choice of the developer & $\begin{array}{l}\text { On a competitive basis with } \\
\text { funding for } 1 / 3 \text { from the municipal } \\
\text { budget }\end{array}$ & $\begin{array}{l}\text { Affiliated large construction } \\
\text { companies. }\end{array}$ \\
\hline
\end{tabular}

\section{Conclusions}

Thus, a comparative analysis of the situation with affordable housing in Austria and Russia shows that in Austria there are principles of social justice, subject to legislation and assistance from state authorities. Meanwhile, in Russia, the housing construction sector is completely subject to the laws of a market economy, in the absence of perfect competition and the development of oligopoly.

However, in the Russian Federation, from the point of view of housing market management, they are increasingly beginning to understand that the sphere of housing construction and housing market management should not be completely outsourced to market relations. To make it more socially oriented form it must be supported with the help of state management organizations. So, for example, in Moscow, such an organization is the GBU (state budgetary institution) "Zhilischnik district". The authors of [12] motivate this by the fact that state management companies are more financially reliable, their purpose is not to obtain commercial benefits (profits), that's why they can set minimum rates for the maintenance of houses by providing them with subsidies from the municipal 
budget; risks when concluding contracts with unscrupulous organizations involved in the maintenance of these houses. As for the construction of new housing, it is currently carried out in all cities of Russia by private construction companies operating under region market laws. Therefore, in many cities with a population of more than one million of people the developers follow the principles of "point building", because in this case they can connect to the existing engineering systems of facilities. The authors of this article see a way out of the current contradictory situation in Russia in the formation and functioning of a socioeconomic cluster in the field of construction and housing and communal services, which will strengthen the role of state authorities in the development of the affordable housing market for socially unprotected segments of the population. These issues are discussed more detailed in [13].

In conclusion, we would like to note that such a positive experience of providing the country's residents with affordable and comfortable housing must be applied in Russia.

\section{References}

1. Wolfgang Foerster. 80 years of social housing in Vienna, http://cms.siel.si/

2. Wolfgang Foerster. 100 years of social housing in Vienna

3. Socialismus v demokracii? Rakousko slaví stoleté výročí sociálního projektu Rudá Vídeň, https://www.info.cz/

4. Vienna's Unique Social Housing Program, https://www.huduser.gov

5. Ing. arch. Anna Koželouhová, doc. Ing. arch. Dagmar Glosová. Koncepce bytové politiky města Vídně školitel: CSc. Ústav navrhování 1, FA VUT v Brně, https://dspace.vutbr.cz/

6. Wiener Wohnen - Gemeindewohnungen, https://www.wien.gv.at/

7. Paweł Kubicki. Idee dla Polski. Polskie miasta nieszczęśliwe? obywatelski thinkletter. Kongres obywatelsky, https://www.kongresobywatelski.pl/

8. Margret Funk. Rent Control in Austria best practice and bad practice. TU Berlin. Industry Seminar Berlin. Rent Regulation in Housing Market - International Perspectives and the Case of Germany, (2017) http:/www.immobilienwirtschaft.tuberlin.de/

9. Maciej Cesarski. Mieszkania na wynajem: wyzwania, doświadczenia, przestrogi. Problemy Rozwoju Miast, 5/2-4, 88 (2008), http://bazhum.muzhp.pl/

10. M.Yu. Borisenok, The new past • the new past, 3. 2017.

11. Christine Whitehead, Kathleen Scanlon. Social Housing in Europe, London School of Economics and Political Science (2007), https://mri.hu/

12. Yu.V. Larionova, A.S. Kovalev, Construction Economics, 1 (61), 40 (2020)

13. L.B. Leonova, V.A. Koksharov, Construction Economics, 6 (60), 69(2019) 